\title{
Silver Precipitation Using Sodium Dithionite in Cyanide Media
}

\author{
Isauro Rivera, ${ }^{1 *}$ Guillermo Juárez, ${ }^{2}$ Francisco Patiño, ${ }^{1}$ Iván A. Reyes, ${ }^{1}$ Antonio Roca, ${ }^{3}$ and María I. Reyes ${ }^{1}$ \\ 1 Área Académica de Ciencias de la Tierra y Materiales, Universidad Autónoma del Estado de Hidalgo, Ciudad Universitaria, \\ Carretera Pachuca-Tulancingo km. 4.5, C.P. 42184, Pachuca Hgo. México. isaurorivera@yahoo.es \\ ${ }^{2}$ Instituto de Minería, Universidad Tecnológica de la Mixteca, Carretera a Acatlima km. 2.5, C.P. 69000, Huajuapan de León, \\ Oaxaca. México. \\ ${ }^{3}$ Facultat de Química. Universitat de Barcelona. Martí i Franquès 1, 08028 Barcelona, Spain.
}

Received September 12, 2011; accepted March 20, 2012

\begin{abstract}
The nature of the reaction and the main parameters affecting $\mathrm{Ag}$ precipitation rate in the system $\mathrm{Ag}^{+}-\mathrm{CN}^{-}-\mathrm{S}_{2} \mathrm{O}_{4}{ }^{2-}$ are studied. From the results obtained, a process of chemical precipitation for $\mathrm{Ag}$ recovery is proposed, using an environmentally-friendly reducing reagent (sodium dithionite, $\mathrm{Na}_{2} \mathrm{~S}_{2} \mathrm{O}_{4}$ ), leaving a residual content of $\mathrm{Ag}$ into the permitted environmental levels $\left(<5 \mathrm{mg} \mathrm{L}^{-1} \mathrm{Ag}\right)$. The levels of $\mathrm{CN}^{-}$in liquids wastes are of the order of $0.816 \mathrm{~mol} \mathrm{~L}^{-1}$, and they can be treated by ozonization processes for inerting cyanide. The results obtained indicate that Ag precipitation is achieved in less than 1 hour, with recoveries close to $99 \%$, at room temperature. Silver precipitation is characterized by an induction period followed by a precipitation period, leaving a metal amount in solution less than $1 \mathrm{mg} \mathrm{L}^{-1}$. The main kinetic parameters studied lead to obtain the following apparent reaction orders: with respect to the initial $\left[\mathrm{S}_{2} \mathrm{O}_{4}{ }^{2-}\right]$ was $n=1.675$, with respect to $\left[\mathrm{CN}^{-}\right]$was -1.24 , with respect to $\left[\mathrm{OH}^{-}\right]$was $\approx 0$ (between $10^{-4}$ and $10^{-2} \mathrm{~mol} \mathrm{~L}^{-1}$ ) and with respect to the initial $\left[\mathrm{Ag}^{+}\right]$was 0.524 . An activation energy of $77 \mathrm{~kJ} \mathrm{~mol}^{-1}$ was obtained. Under these conditions, $\mathrm{Ag}$ precipitation in the system $\mathrm{Ag}^{+}-\mathrm{CN}^{-}-\mathrm{S}_{2} \mathrm{O}_{4}{ }^{2-}$ is controlled by chemical reaction, characterized by high activation energy, and is independent of the hydrodynamic variables of the system.
\end{abstract}

Key words: Silver precipitation, sodium dithionite, sodium cyanide, chemical kinetics, reaction order.

\section{Introduction}

The recovery of silver from secondary sources, such as effluents coming from metallurgical processes [1], hydrometallurgy [2], electrolysis [3,4], the metallic coating industry, photographic effluents [5], among others, is an attractive activity due to its economic value. These effluents are also considered as toxic and dangerous residues.

Generally, the silver effluents are present in a complex form, such as thiosulphate $\left(\mathrm{S}_{2} \mathrm{O}_{3}{ }^{2-}\right)$ or cyanide $\left(\mathrm{CN}^{-}\right)$media and they cannot be discharged into public drainage without a previous detoxification treatment [6]. Several studies have been developed to recover silver from industrial effluents, such as cementation $[7,8]$, electrolytic recovery [9-10], ion exchange resins [11-13]. However, these processes have technical difficulties, related to the metal percent of recovery and relatively low purity of silver obtained. These processes can be too expensive for small and medium producers; they can also generate highly dangerous residues [14-16].

Rivera et al., [17] studied the silver precipitation in elemental form in the $\mathrm{S}_{2} \mathrm{O}_{3}{ }^{2-}-\mathrm{S}_{2} \mathrm{O}_{4}{ }^{2-}$ system. In this work it was
Resumen. Se ha estudiado la naturaleza de la reacción y los principales parámetros que afectan la velocidad de precipitación en el sistema $\mathrm{Ag}^{+}-\mathrm{CN}^{-}-\mathrm{S}_{2} \mathrm{O}_{4}{ }^{2-}$. De los resultados obtenidos, se propone un proceso de precipitación química para la recuperación de $\mathrm{Ag}$ usando un reactivo reductor amigable con el medio ambiente (ditionito de sodio, $\mathrm{Na}_{2} \mathrm{~S}_{2} \mathrm{O}_{4}$ ), que deja un residuo de $\mathrm{Ag}$ dentro de los niveles ambientales permitidos $\left(<5 \mathrm{mg} \mathrm{L}^{-1} \mathrm{Ag}\right)$. Los niveles de $\mathrm{CN}^{-}$en los líquidos residuales son del orden de $0.816 \mathrm{~mol} \mathrm{~L}^{-1} \mathrm{y}$ pueden ser tratados por procesos de ozonización para la inertización del cianuro. Los resultados obtenidos indican que la precipitación de Ag se logra en menos de una hora, con recuperaciones cercanas a $99 \%$ a temperatura ambiente. La precipitación de la plata se caracteriza por un periodo de inducción, seguido de un periodo de precipitación, dejando una cantidad de metal en solución de menos de $1 \mathrm{mg} \mathrm{L}^{-1}$. Los principales parámetros cinéticos estudiados llevan a la obtención de los siguientes órdenes de reacción aparentes: Con respecto a la $\left[\mathrm{S}_{2} \mathrm{O}_{4}{ }^{2-}\right]$ inicial, fue de $n=1.675$; con respecto a $\left[\mathrm{CN}^{-}\right]$, fue de -1.24 ; con respecto a $\left[\mathrm{OH}^{-}\right]$, fue de $\approx 0$ (entre $10^{-4}$ y $\left.10^{-2} \mathrm{~mol} \mathrm{~L}^{-1}\right)$, y con respecto a la $\left[\mathrm{Ag}^{+}\right]$inicial, fue de 0.524 . Se obtuvo una energía de activación de 77 $\mathrm{kJ} \mathrm{mol}^{-1}$. Bajo estas condiciones, la precipitación de $\mathrm{Ag}$ en el sistema $\mathrm{Ag}^{+}-\mathrm{CN}^{-}-\mathrm{S}_{2} \mathrm{O}_{4}{ }^{2-}$ está controlada por la reacción química, se caracteriza por una elevada energía de activación y es independiente de las variables hidrodinámicas del sistema.

Palabras clave: Precipitación de plata, ditionito de sodio, cianuro de sodio, cinética química, orden de reacción.

found that silver precipitation was characterized by an induction period, followed by a conversion (precipitation) period, until almost all the silver was precipitated, leaving in solution a metal amount less than $1 \mathrm{ppm}$. Aggregates of individual crystals with a size less than $0.5 \mu \mathrm{m}$ were obtained. In dithionite medium, $1 \mathrm{~mol}$ dithionite can precipitate $2 \mathrm{~mol}$ of silver, whereas without thiosulphate in the reaction system, $1 \mathrm{~mol}$ dithionite precipitated $6 \mathrm{~mol}$ of silver. In the kinetic study and in the induction period, the inverse of this parameter was proportional to $\left[\mathrm{S}_{2} \mathrm{O}_{4}{ }^{2-}\right]^{0.4}$ and apparent activation energy of $108 \mathrm{~kJ} \mathrm{~mol}^{-1}$ was obtained. During the precipitation period, the reaction order with respect to $\left[\mathrm{S}_{2} \mathrm{O}_{3}{ }^{2-}\right]$ was $n=-3$, with respect to the initial $\left[\mathrm{S}_{2} \mathrm{O}_{4}{ }^{2-}\right] n=0.9$, with respect to $\left[\mathrm{OH}^{-}\right]$ and the initial $\left[\mathrm{Ag}^{+}\right]$was $n \approx 0$. An activation energy of $52 \mathrm{~kJ}$ $\mathrm{mol}^{-1}$ was obtained.

In the present work, the nature of the precipitation reaction of silver involved in cyanide solutions is studied. The kinetic study carried out involves the following parameters: rate and system of stirring, $\left[\mathrm{CN}^{-}\right]$, initial $\left[\mathrm{S}_{2} \mathrm{O}_{4}{ }^{2-}\right],\left[\mathrm{OH}^{-}\right]$, initial $\left[\mathrm{Ag}^{+}\right]$, and temperature. A chemical precipitation process is proposed using sodium dithionite $\left(\mathrm{Na}_{2} \mathrm{~S}_{2} \mathrm{O}_{4}\right)$ as reducing reagent, for the 
recovery of silver, in the system $\mathrm{Ag}^{+}-\mathrm{CN}^{-}-\mathrm{S}_{2} \mathrm{O}_{4}{ }^{2-}$. A comparative study of silver precipitation using sodium dithionite, in thiosulphate and also in cyanide media is also included.

\section{Results and discussion}

Nature of the silver precipitation reaction using sodium dithionite in cyanide medium

A preliminary experiment has been carried out with experimental conditions selected from results obtained in a previous work [18]: Temperature $25^{\circ} \mathrm{C},\left[\mathrm{S}_{2} \mathrm{O}_{4}{ }^{2-}\right]=0.115 \mathrm{~mol} \mathrm{~L}^{-1}$, [ $\left.\mathrm{CN}^{-}\right]$ $=0.0816 \mathrm{~mol} \mathrm{~L}^{-1}, \mathrm{pH}=11$, stirring rate $500 \mathrm{~min}^{-1},\left[\mathrm{Ag}^{+}\right]=$ $0.0278 \mathrm{~mol} \mathrm{~L}^{-1}$. Figure 1 shows the silver conversion $\left(\mathrm{X}_{\mathrm{Ag}}\right)$ versus time. This graph presents a behavior in two steps: a first step corresponding to an induction period $(5 \mathrm{~min})$ and a second step corresponding to the precipitation period (40 min). During the induction period, no precipitation was detected, only color change of solution, from colorless to gray color. This period corresponds to the nucleation of silver crystals. The precipitation period corresponds to the growth process of these crystals, and silver precipitation is almost total. From this experiment and other preliminary experiments [18], the duration of the induction period was small, and consequently, no seeding was used in any experiment of this work.

The recovery of silver has been higher than $99 \%$ in 45 minutes and the product obtained was metallic silver (Figure 2).

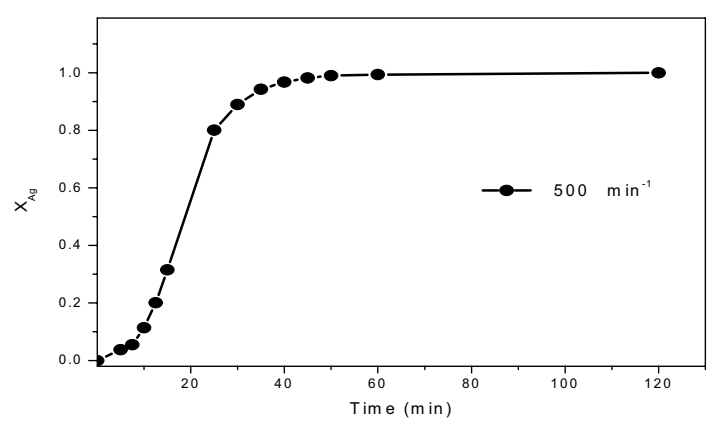

Fig. 1. Ag precipitation: $\left[\mathrm{S}_{2} \mathrm{O}_{4}{ }^{2-}\right]=0.115 \mathrm{~mol} \mathrm{~L}^{-1} ; \mathrm{T}=25^{\circ} \mathrm{C} ;\left[\mathrm{CN}^{-}\right]=$ $0.0816 \mathrm{~mol} \mathrm{~L}^{-1} ;\left[\mathrm{Ag}^{+}\right]=0.0278 \mathrm{~mol} \mathrm{~L}^{-1}$; Stirring rate $=500 \mathrm{~min}^{-1}$.

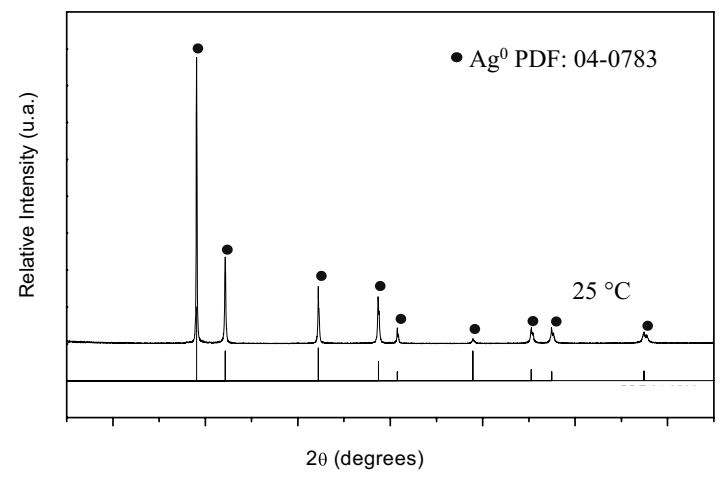

Fig. 2. XR Difractogram of the obtained silver (PDF 04-0783).
Figure 3 shows and image obtained by SEM (secondary electrons, SE) of the obtained precipitate (Ag), showing that the morphology of particles consists of crystalline aggregates of tenths micrometers, soldering each other and formed by micro crystals of spherical form, with sizes varying from 0.1 to $1 \mu \mathrm{m}$. These precipitates are similar to those obtained in the system $\mathrm{Ag}^{+}-\mathrm{S}_{2} \mathrm{O}_{3}{ }^{2-}-\mathrm{S}_{2} \mathrm{O}_{4}{ }^{2-}$ [17]. Figure 4 shown a spectrum obtained by SEM-EDS corresponding to the mentioned crystals, were silver appears as the only element in the precipitated. In addition elemental analysis by AAS was performed, obtained a purity of $99.8 \%$ of silver.

The rate of oxidation of sodium dithionite was studied under the following experimental conditions: $25{ }^{\circ} \mathrm{C}$; $\left[\mathrm{S}_{2} \mathrm{O}_{4}{ }^{2-}\right]$ $=0.115 \mathrm{~mol} \mathrm{~L}^{-1} ;\left[\mathrm{CN}^{-}\right]=0.0816 \mathrm{~mol} \mathrm{~L}^{-1} ;\left[\mathrm{Ag}^{+}\right]=0.0278 \mathrm{~mol}$ $\mathrm{L}^{-1} ; \mathrm{pH}=11$ and stirring rate $500 \mathrm{~min}^{-1}$. The results show that the dithionite during the first 45 min was oxidized in $30 \%$ as sulfites. At the same time, the reaction of precipitation of silver occurs in parallel form, therefore, at this time interval there is enough dithionite ( $70 \%$ of the initial concentration) so that the reaction of silver precipitation occurs. At times over to 120 min there is an oxidation of dithionite around of the $80 \%$. The dithionite oxidation process is as follows:

$$
2\left(\mathrm{~S}_{2} \mathrm{O}_{4}\right)^{2-}{ }_{(\mathrm{aq})}+\mathrm{O}_{2(\mathrm{aq})}+4 \mathrm{OH}^{-}{ }_{(\mathrm{aq})} \Rightarrow 4 \mathrm{SO}_{3}{ }^{2-}{ }_{(\mathrm{aq})}+2 \mathrm{H}_{2} \mathrm{O}
$$

The presence of sulfites in the residual liquids after precipitation was confirmed by iodometry and ionic chromatogra-

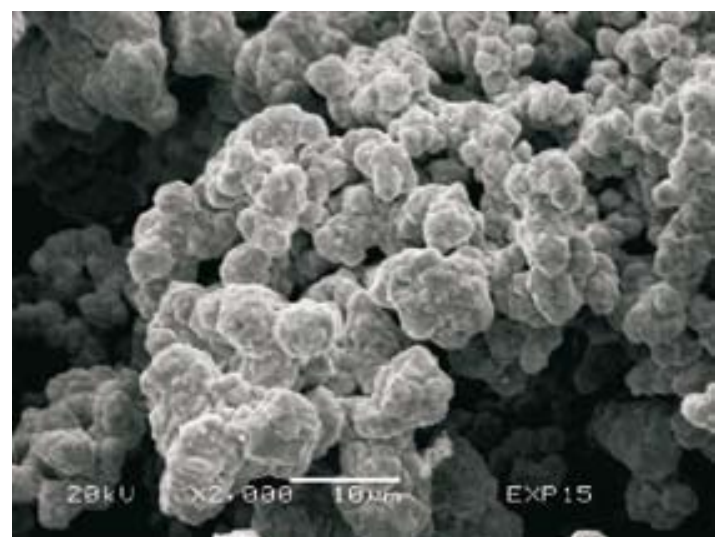

Fig. 3. Image obtained by SEM-SE of silver precipitate.

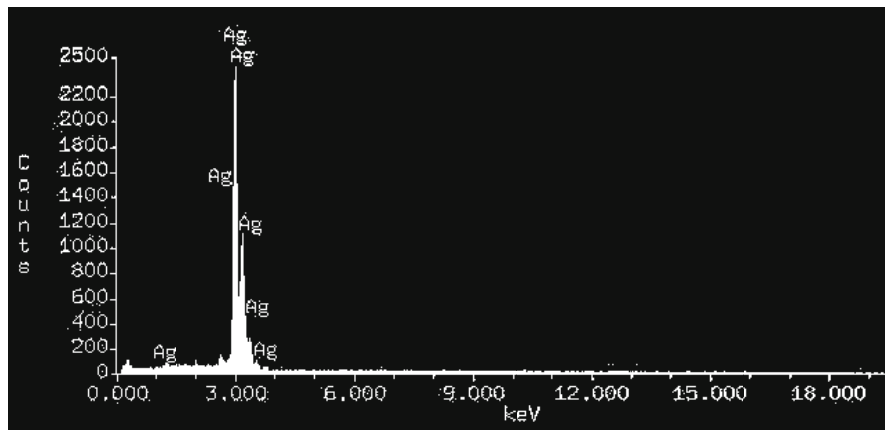

Fig. 4. SEM-EDS spectrum corresponding to the precipitate. 
phy. The quantitative analysis confirms that all dithionite was oxidized as sulfite.

\section{Kinetic study of silver precipitation in cyanide medium}

The effect of stirring rate over silver precipitation (Figure 5) was carried out in the range of $100-1000 \mathrm{~min}^{-1} . K_{\text {exp }}$ for each experiment was obtained as the slope in the graph $X_{\mathrm{Ag}}$ vs. time, which measures the precipitation rate. For all the experiments with magnetic stirring the induction time was similar, and a $K_{\text {exp }}$ of $0.060 \mathrm{~min}^{-1}$ was obtained, indicating that there was not effect of stirring rate in the interval studied. One additional experiment was carried out using mechanical stirring. The rate obtained was almost the same as with magnetic stirring. Consequently, the silver precipitation rate is independent of the stirring system used, in the experimental conditions employed. However, and for higher reaction time silver was partially redissolved. For a stirring speed of $100 \mathrm{~min}^{-1}$, the induction time is higher with respect to the experiments carried out at 500 and $1000 \mathrm{~min}^{-1}$. Consequently, a stirring speed of $500 \mathrm{~min}^{-1}$ was chosen for the systematic study carried out, to minimize the induction time of this process.

The effect of initial dithionite concentration on silver precipitation (Figure 6) was determined in the range between 0.029 and $0.115 \mathrm{~mol} \mathrm{~L}^{-1} \mathrm{~S}_{2} \mathrm{O}_{4}{ }^{2-}$. Figure 7 is a plot of $\log K_{\text {exp }}$ versus

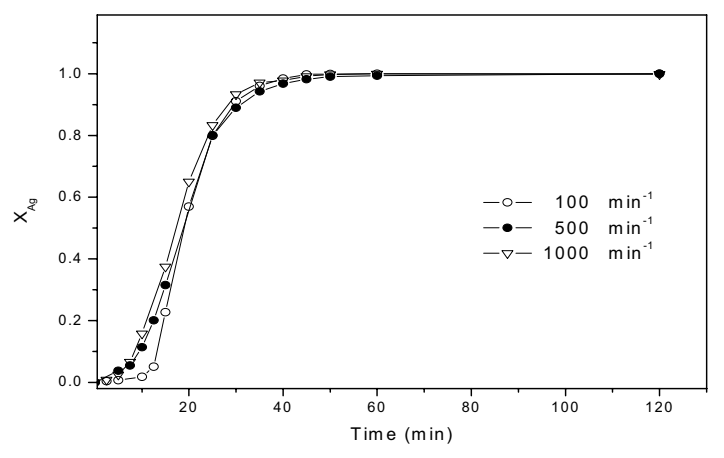

Fig. 5. Effect of stirring rate on silver precipitation $\left(\mathrm{T}=25^{\circ} \mathrm{C} ; \mathrm{pH}\right.$ $=11 ;\left[\mathrm{S}_{2} \mathrm{O}_{4}{ }^{2-}\right]=0.115 \mathrm{~mol} \mathrm{~L}^{-1} ;\left[\mathrm{CN}^{-}\right]=0.0816 \mathrm{~mol} \mathrm{~L}^{-1} ;\left[\mathrm{Ag}^{+}\right]=$ $0.0278 \mathrm{~mol} \mathrm{~L}^{-1}$ ).

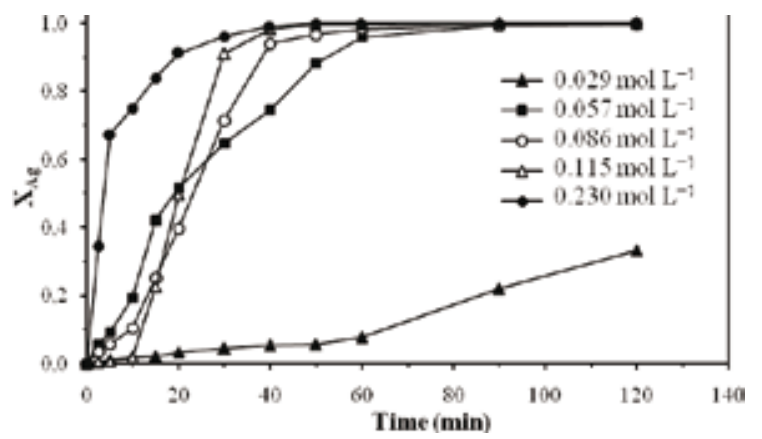

Fig. 6. Effect of $\mathrm{S}_{2} \mathrm{O}_{4}{ }^{2-}$ concentration on silver precipitation. $\mathrm{T}=25$ ${ }^{\circ} \mathrm{C} ; \mathrm{pH}=11 ;\left[\mathrm{CN}^{-}\right]=0.0816 \mathrm{~mol} \mathrm{~L}^{-1}$; stirring rate $=500 \mathrm{~min}^{-1} ;\left[\mathrm{Ag}^{+}\right]$ $=0.0278 \mathrm{~mol} \mathrm{~L}^{-1}$. $\log \left[\mathrm{S}_{2} \mathrm{O}_{4}{ }^{2-}\right]$. The apparent reaction order obtained was $n=$ 1.675 , indicating and important effect of this variable in the reaction rate.

The effect of cyanide concentration on silver precipitation was determined in the range of 0.0612 and $0.1633 \mathrm{~mol} \mathrm{~L}^{-1}$ (Figure 8). When cyanide concentration increased, the silver precipitation rate diminished. Figure 9 is a plot of the $\log$ of the precipitation rate $\left(\log K_{\text {exp }}\right)$ versus $\log \left[\mathrm{CN}^{-}\right]$. The reaction order obtained was of $n=-1.24$. In these conditions, the noncomplexed silver concentration is very low (see eq. 5), and this concentration decreases sharply as the cyanide concentra-

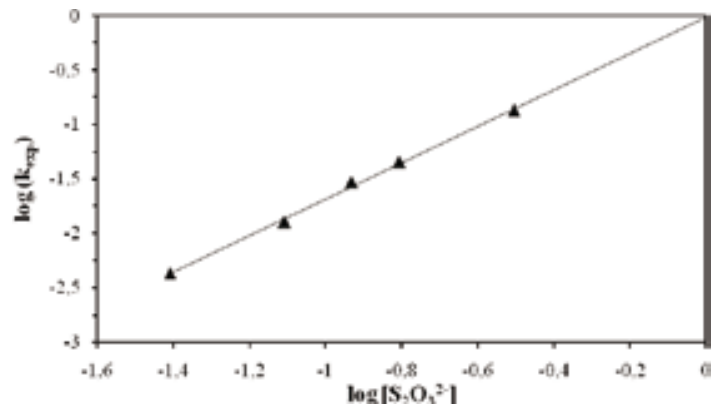

Fig. 7. Dependence of $\mathrm{K}_{\exp }$ versus $\mathrm{S}_{2} \mathrm{O}_{4}{ }^{2-}$ concentration: reaction order of 1.675 .

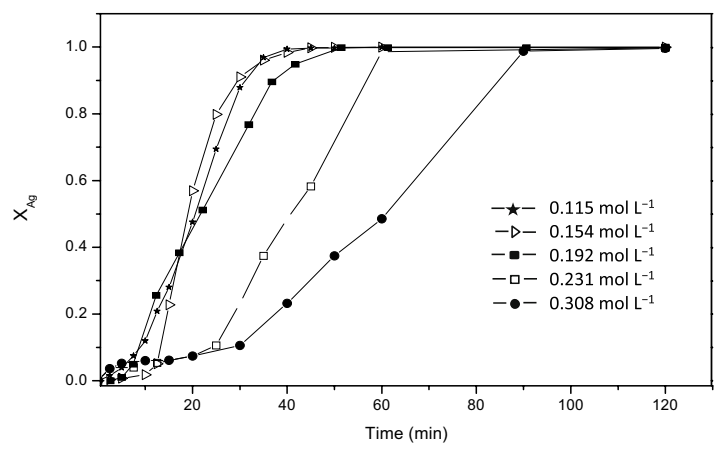

Fig. 8. Effect of $\mathrm{CN}^{-}$concentration on silver precipitation $\left(\mathrm{T}=25^{\circ} \mathrm{C}\right.$; $\mathrm{pH}=11 ;\left[\mathrm{S}_{2} \mathrm{O}_{4}{ }^{2-}\right]=0.115 \mathrm{~mol} \mathrm{~L}^{-1}$; stirring rate $=500 \mathrm{~min}^{-1} ;\left[\mathrm{Ag}^{+}\right]$ $=0.0278 \mathrm{~mol} \mathrm{~L}^{-1}$ ).

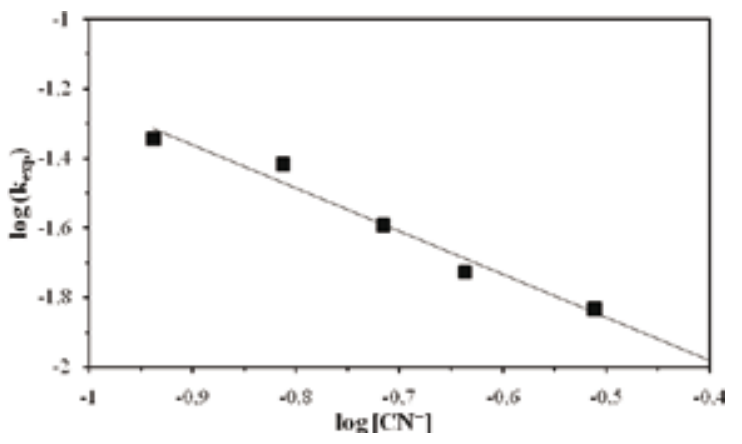

Fig. 9. Dependence of $\mathrm{K}_{\mathrm{exp}}$ versus $\mathrm{CN}^{-}$concentration: reaction order of -1.24 . 
tion increases, obtaining a negative apparent reaction order of -1.24 .

The effect of $\mathrm{OH}^{-}$concentration on silver precipitation was determined in the range of $1 \times 10^{-5}-1 \times 10^{-2} \mathrm{~mol} \mathrm{~L}^{-1}$ (Figure 10). A $K_{\text {exp }}$ of $0.17077 \mathrm{~min}^{-1}$ was obtained for $\mathrm{OH}^{-}$concentration of $1 \cdot 10^{-5} \mathrm{~mol} \mathrm{~L}^{-1}$ and a $K_{\text {exp }}$ of $0.06029 \mathrm{~min}^{-1}$ for an $\mathrm{OH}^{-}$concentration of $1 \times 10^{-4} \mathrm{~mol} \mathrm{~L}^{-1}, 1 \times 10^{-3} \mathrm{~mol} \mathrm{~L}^{-1}$ and 1 $\times 10^{-2} \mathrm{~mol} \mathrm{~L}^{-1}$. In the last range, the reaction order was of $n \cong 0$; therefore, there is no significant effect of the $\left[\mathrm{OH}^{-}\right]$on the rate of precipitation of silver under the conditions studied here.

Figure 11 includes the effect of temperature on silver precipitation in the range of $15{ }^{\circ} \mathrm{C}(280 \mathrm{~K})$ and $65{ }^{\circ} \mathrm{C}(338 \mathrm{~K})$. Figure 12 is a plot of $\ln K_{\text {exp }}$ vs. $1000 / \mathrm{T}$ (interval $25-55^{\circ} \mathrm{C}$ ), obtaining an activation energy of $77 \mathrm{~kJ} \mathrm{~mol}^{-1}$. The controlling step of the process is the chemical reaction itself (chemical control), in the experimental conditions employed. The obtained product at $15{ }^{\circ} \mathrm{C}$ and $25{ }^{\circ} \mathrm{C}$ corresponds to metallic silver as the only specie present (Figure 2). At temperatures of $35^{\circ} \mathrm{C}$ and $45^{\circ} \mathrm{C}$ formation of $\mathrm{Ag}_{2} \mathrm{~S}$ appears in incipient manner; but this formation increases at temperatures over to $45^{\circ} \mathrm{C}$, obtaining a similar behavior to Rivera et al. [17] in the system $\mathrm{Ag}-\mathrm{S}_{2} \mathrm{O}_{3}{ }^{2-}-\mathrm{S}_{2} \mathrm{O}_{4}{ }^{2-}$. The sulfur content in these precipitates was determined by Elemental analysis: $15^{\circ} \mathrm{C}$ and $25^{\circ} \mathrm{C},<0.01 \% \mathrm{~S}\left(\cong 0.07 \% \mathrm{Ag}_{2} \mathrm{~S}\right) ; 35$

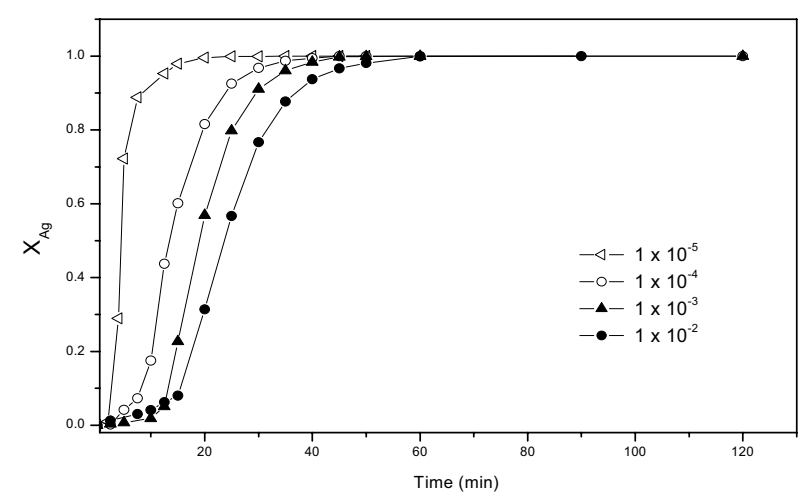

Fig. 10. Effect of $\mathrm{OH}^{-}$concentration on silver precipitation $(\mathrm{T}=25$ ${ }^{\circ} \mathrm{C} ;\left[\mathrm{S}_{2} \mathrm{O}_{4}^{2-}\right]=0.115 \mathrm{~mol} \mathrm{~L}^{-1} ;\left[\mathrm{CN}^{-}\right]=0.0816 \mathrm{~mol} \mathrm{~L}{ }^{-1}$; stirring rate $\left.=500 \mathrm{~min}^{-1} ;\left[\mathrm{Ag}^{+}\right]=0.0278 \mathrm{~mol} \mathrm{~L}^{-1}\right)$.

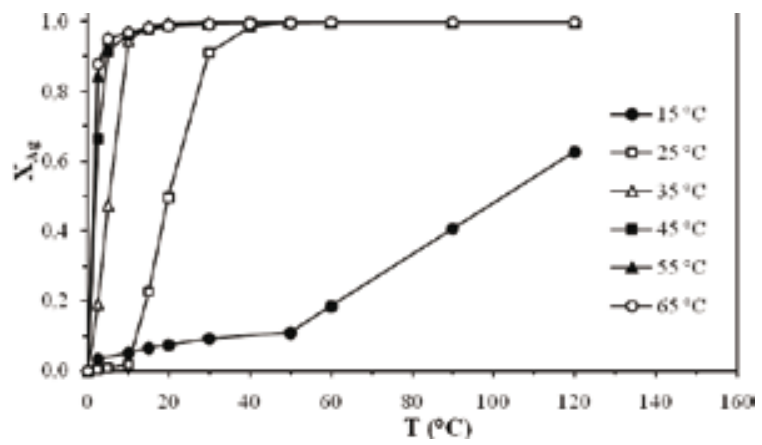

Fig. 11. Effect of temperature on silver precipitation $\left[\mathrm{CN}^{-}\right]=0.0816$ $\mathrm{mol} \mathrm{L}-1 ; \mathrm{pH}=11 ;\left[\mathrm{S}_{2} \mathrm{O}_{4}^{2-}\right]=0.115 \mathrm{~mol} \mathrm{~L}^{-1}$; stirring rate $=500 \mathrm{~min}^{-1}$; $\left[\mathrm{Ag}^{+}\right]=0.0278 \mathrm{~mol} \mathrm{~L}^{-1}$.
${ }^{\circ} \mathrm{C}, 0.42 \% \mathrm{~S}\left(\cong 3.25 \% \mathrm{Ag}_{2} \mathrm{~S}\right) ; 45{ }^{\circ} \mathrm{C}, 1.12 \% \mathrm{~S}\left(\cong 8.67 \% \mathrm{Ag}_{2} \mathrm{~S}\right)$; $55{ }^{\circ} \mathrm{C}, 6.80 \% \mathrm{~S}\left(\cong 52.67 \% \mathrm{Ag}_{2} \mathrm{~S}\right)$ and $65{ }^{\circ} \mathrm{C}, 12.4 \% \mathrm{~S}(\cong 96 \%$ $\left.\mathrm{Ag}_{2} \mathrm{~S}\right)$ at $55^{\circ} \mathrm{C}$ or higher a mixture of metallic silver and silver sulfide was obtained. Thus, the effect of temperature on silver precipitation (as metallic silver) was determined in the interval of $15-55^{\circ} \mathrm{C}$ and the results are shown in Figure 12.

The effect of initial silver concentration (Figure 13) was determined in the range between $0.0139 \mathrm{~mol} \mathrm{~L}^{-1}$ and 0.0347 mol L $\mathrm{L}^{-1}$. Figure 14 is a plot of $\log K_{\text {exp }}$ vs. $\log \left[\mathrm{Ag}^{+}\right]$initial. The apparent reaction order was of $n=0.524$.

It is possible to obtain silver recoveries of $99 \%$ from silvercyanide liquids in the presence of dithionite solutions, at room temperature, leading to an amount of silver in these liquids near to $1 \mathrm{ppm}$, level permitted by the international environmental regulations $\left(<4.63 \times 10^{-5} \mathrm{~mol} \mathrm{~L}^{-1} \mathrm{Ag}, 5 \mathrm{ppm} \mathrm{Ag}\right)$, in the experimental conditions employed. The optimal conditions for the precipitation process are as follows: $\left[\mathrm{Ag}^{+}\right]=0.0278 \mathrm{~mol} \mathrm{~L}^{-1}$, $\left[\mathrm{S}_{2} \mathrm{O}_{4}{ }^{2-}\right]=0.115 \mathrm{~mol} \mathrm{~L}^{-1} ;\left[\mathrm{CN}^{-}\right]=0.0816 \mathrm{~mol} \mathrm{~L}^{-1}$; Temperature $=25^{\circ} \mathrm{C}$; Stirring rate $=500 \mathrm{~min}^{-1}$; and $\mathrm{pH}=11$. The steps for the application of this process includes: nucleation of silver crystals, the precipitation of this metal, and filtration. Silver metallic obtained needs to be smelted and refined and effluents needs to be detoxified, being one of them the ozonization process for cyanides. Several authors have established the best conditions for the treatment of these kinds of cyanide effluents [19-21]. After these, the remaining sulfites can be oxidized to sulphates and precipitated as calcium sulphate [22].

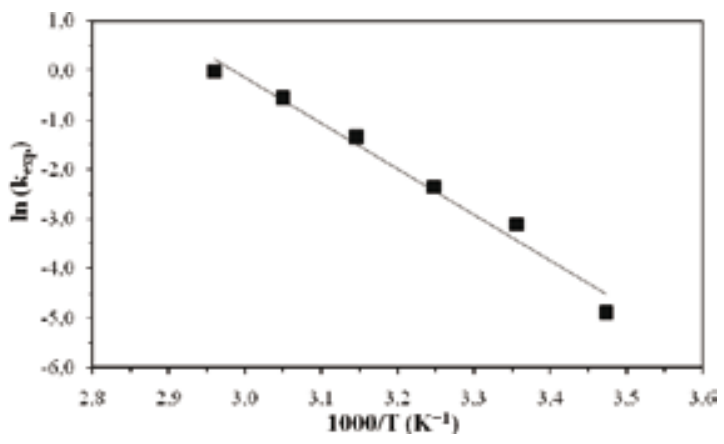

Fig. 12. Dependence of $K_{\text {exp }}$ versus temperature. Apparent activation energy $=77 \mathrm{~kJ} \cdot \mathrm{mol}^{-1}$.

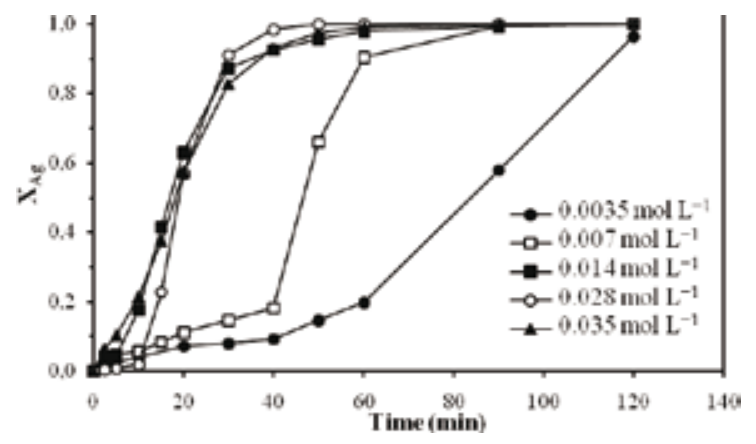

Fig. 13. Effect of initial $\mathrm{Ag}^{+}$concentration on silver precipitation $(\mathrm{T}=$ $25^{\circ} \mathrm{C} ; \mathrm{pH}=11 ;\left[\mathrm{S}_{2} \mathrm{O}_{4}{ }^{2-}\right]=0.115 \mathrm{~mol} \mathrm{~L}^{-1}$; stirring rate $=500 \mathrm{~min}^{-1}$. 


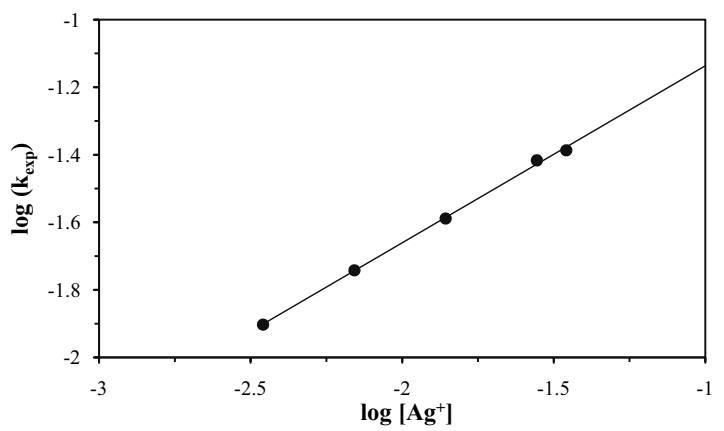

Fig. 14. Dependence of $K_{\text {exp }}$ versus initial silver concentration: reaction order of 0.524 .

\section{Application to a real industrial sample}

The optimal conditions corresponding to the process of silver precipitation was applied to a real industrial sample with cyanide base. This sample comes from cyanidation stage; the main components of this industrial solution are: $\mathrm{Ag}=3.1 \times 10^{-3} \mathrm{~mol}$ $\mathrm{L}^{-1} ; \mathrm{Pb}=1.3 \times 10^{-3} \mathrm{~mol} \mathrm{~L}^{-1} ; \mathrm{Cu}=9.3 \times 10^{-4} \mathrm{~mol} \mathrm{~L}^{-1} ; \mathrm{Zn}=7.1$ $\times 10^{-4} \mathrm{~mol} \mathrm{~L}^{-1} ; \mathrm{Fe}=1.0 \times 10^{-2} \mathrm{~mol} \mathrm{~L}^{-1} ; \mathrm{Au}=6.1 \times 10^{-5} \mathrm{~mol}$ $\mathrm{L}^{-1} ;\left[\mathrm{CN}^{-}\right]=3.1 \times 10^{-2} \mathrm{~mol} \mathrm{~L}^{-1}$ and $\mathrm{pH} 11$. The silver precipitation experiment was realized under the following conditions: Temperature $25{ }^{\circ} \mathrm{C},\left[\mathrm{S}_{2} \mathrm{O}_{4}{ }^{2-}\right]=0.115 \mathrm{~mol} \mathrm{~L}^{-1}, \mathrm{pH}=11$ and stirring rate $500 \mathrm{~min}^{-1}$. The precipitation of $\mathrm{Ag}$ was completed in $45 \mathrm{~min}$, remaining in the liquid waste concentrations of $\mathrm{Ag}$ $<3$ ppm. $\mathrm{Pb}, \mathrm{Cu}, \mathrm{Zn}, \mathrm{Fe}$ and $\mathrm{Au}$ stay practically to the initial concentrations; silver recovery was $99.82 \%$. The precipitate was characterized by wet chemical analysis finding a silver purity of $99.82 \%$. Also, the percentages of impurities contained in the precipitate were: $\mathrm{Pb}=0.022 \%, \mathrm{Cu}=0.005 \%, \mathrm{Zn}=$ $0.083 \%, \mathrm{Fe}=0.046 \%$ and $\mathrm{Au}=0.026 \%$. In addition the precipitate was characterized by XRD and SEM-EDS; these analyses indicate the presence of metallic silver as the only specie present, confirming the result obtained by wet chemical analysis.

\section{Comparative study of silver precipitation using sodium dithionite, in cyanide and thiosulphate media}

Table 1 shows the main kinetic parameters obtained in the study of silver precipitation with sodium dithionite in thiosul- phate media (Rivera et al., 2007) and in cyanide media (this work).

In both cases, the reaction order with respect to the $\mathrm{OH}^{-}$ concentration is the same and the activation energies are similar. The major effects in cyanide are the variables initial dithionite concentration (reaction order $n=1.675$ ) and initial silver concentration (reaction order $n=0.524$ ), whereas for thiosulphate media the major effect is the thiosulphate concentration (reaction order $n=-3$ ). By using standard operating conditions in cyanide media and in thiosulphate media the precipitation reaction rates are similar.

\section{Conclusions}

Silver precipitation in the $\mathrm{Ag}^{+}-\mathrm{CN}^{-}-\mathrm{S}_{2} \mathrm{O}_{4}{ }^{2-}$ system under the experimental conditions: temperature $25{ }^{\circ} \mathrm{C} ;\left[\mathrm{S}_{2} \mathrm{O}_{4}{ }^{2-}\right]=0.115$ $\left.\mathrm{mol} \mathrm{L}-1 ; \mathrm{CN}^{-}\right]=0.0816 \mathrm{~mol} \mathrm{~L}{ }^{-1} ; \mathrm{pH}=11$; stirring rate $=500$ $\left.\min ^{-1} ; \mathrm{Ag}^{+}\right]=0.0278 \mathrm{~mol} \mathrm{~L}^{-1}$, is characterized by a two-steps process: an induction period, and a precipitation period with silver conversion to metallic form. During the induction period no important silver precipitation is observed and corresponds to the nucleation period of silver crystals. The silver precipitation starts and proceeds during the second step. During the precipitation step, silver recoveries are higher than $99 \%$, obtaining metallic silver of high purity as the only species; silver amount in the resulting liquids is near to $1 \mathrm{ppm}$, level permitted by the international environmental regulations $\left(<4.63 \times 10^{-5}\right.$ mol L $\left.{ }^{-1} \mathrm{Ag}, 5 \mathrm{ppm} \mathrm{Ag}\right)$. The rate obtained using mechanical stirring $\left(500 \mathrm{~min}^{-1}\right)$ was almost the same as with magnetic stirring (range 100-1000 $\mathrm{min}^{-1}$ ). Consequently, the silver precipitation rate is independent of the stirring system used. In the conversion period, the apparent reaction order with respect to $\mathrm{OH}^{-}$concentration was $n \cong 0$ in the range between $1 \times 10^{-4}$ $-1 \times 10^{-2} \mathrm{~mol} \mathrm{~L}^{-1}$, with respect to initial $\mathrm{S}_{2} \mathrm{O}_{4}{ }^{2-}$ concentration was $n=1.675\left(0.029 \mathrm{~mol} \mathrm{~L}^{-1}-0.115 \mathrm{~mol} \mathrm{~L}^{-1}\right)$, with respect to the initial $\mathrm{Ag}^{+}$concentration was $n=0.524(0.0139-0.0347$ $\left.\mathrm{mol} \mathrm{L}^{-1}\right)$ and with respect to the cyanide concentration was $n=$ $-1.24\left(0.0612-0.1633 \mathrm{~mol} \mathrm{~L}^{-1} \mathrm{CN}^{-}\right)$. In the last case, the noncomplexed silver concentration in solution is very low and this concentration decreases sharply as the cyanide concentration increases, obtaining the indicated negative apparent reaction

Table 1. Main kinetic parameters for silver precipitation in cyanide and thiosulphate media.

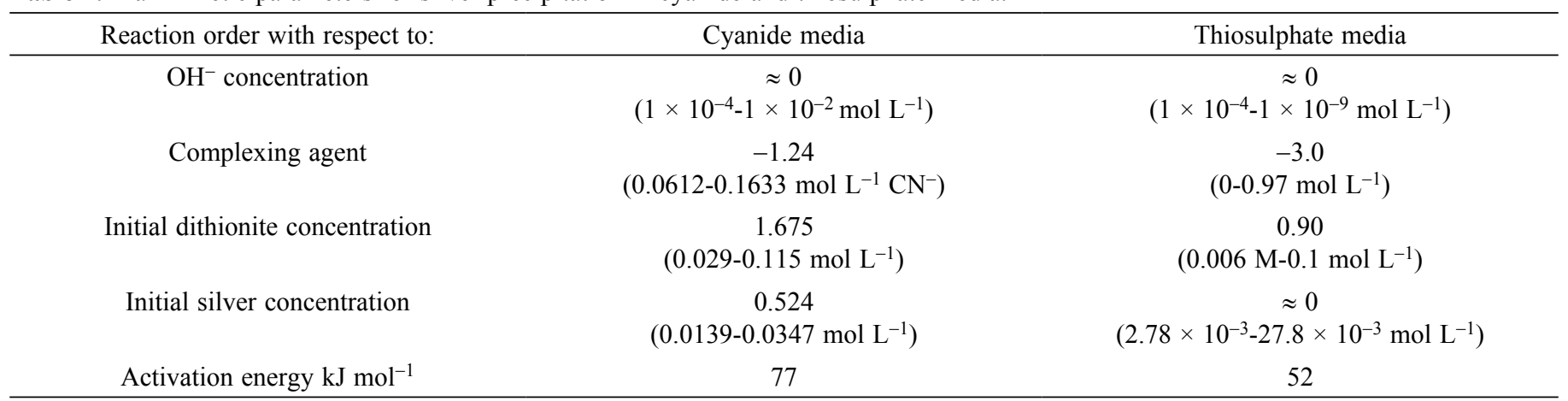


order. An apparent activation energy of $77 \mathrm{~kJ} \mathrm{~mol}^{-1}$ for the precipitation step was obtained in the range between $25-55^{\circ} \mathrm{C}$, indicating a chemical control during the process.

\section{Experimental Procedure}

The silver precipitation experiments were done at atmospheric pressure into a conventional glass kettle of $500 \mathrm{ml}$ of capacity, on a heating plate with magnetic stirring, equipped with a stirring gauge and a temperature controller. $\mathrm{pH}$ measurement was done with a $\mathrm{pH}$ meter, with an electrode that works under extreme conditions of acidity and alkalinity (0-14). Adjustments of $\mathrm{pH}$ were done by addition of $\mathrm{NaOH} 0.5 \mathrm{~mol} \mathrm{~L}^{-1}$ solution. The temperature of the system at room temperature was controlled and measured with a contact thermometer and an ATC attached to the $\mathrm{pHmeter}$, while for the tests done at elevated temperature, the control was carried out with a thermoregulatory device to maintain batch temperature constant, with a tolerance of $0.5^{\circ} \mathrm{C}$. Silver solutions were done with high purity $\mathrm{AgNO}_{3}$.

The progress of the reaction was realized prefixing times to take samples during the precipitation reaction. Silver precipitation started when solid sodium dithionite was added to the silver-cyanide solutions (the dithionite dissolution is instantaneous in this system). Solutions obtained were analyzed by atomic absorption spectrometry (AAS) for determination of silver a prefixed time and the final solid product was characterized by X-Ray Diffraction (XRD) and Scanning Electron Microscopy (SEM).

The fraction of Ag was calculated according to the following expressions:

$$
\begin{gathered}
X_{S}=\frac{[A g]_{S O L}}{[A g]_{T}} \\
X_{P}=1-X_{S}
\end{gathered}
$$

Where: $X_{S}=A g$ fraction in solution; $X_{P}=A g$ precipitated fraction; $[\mathrm{Ag}]_{\mathrm{T}}=$ Initial $\mathrm{Ag}$ concentration and $[\mathrm{Ag}]_{\mathrm{sol}}=\mathrm{Ag}$ concentration in solution at time $t$.

The reaction for silver reduction from cyanide effluents must be done according to the following equation [19]:

$$
\begin{gathered}
\mathrm{S}_{2} \mathrm{O}_{4}{ }^{2-}{ }_{(\mathrm{aq})}+ \\
4 \mathrm{OH}^{-}{ }_{(\mathrm{aq})}+2 \mathrm{Ag}^{+}{ }_{(\mathrm{aq})} \\
2 \mathrm{SO}_{3}{ }^{2-}{ }_{(\mathrm{aq})}+2 \mathrm{H}_{2} \mathrm{O}
\end{gathered} \Rightarrow 2 \mathrm{Ag}^{0}{ }_{(\mathrm{s})}+
$$

In the presence of cyanide, silver is as a stable complex, with an equilibrium constant [23], which can be expressed according to equation 5 :

$$
\begin{gathered}
{\left[\mathrm{Ag}(\mathrm{CN})_{2}\right]_{(\mathrm{aq})}^{-} \Leftrightarrow \mathrm{Ag}^{+}{ }_{(\mathrm{aq})}+2 \mathrm{CN}^{-}{ }_{(\mathrm{aq})}} \\
\mathrm{K}_{\mathrm{e}\left(25^{\circ} \mathrm{C}\right)}=10^{-19.85}
\end{gathered}
$$

This value indicates that silver cyanide complex is very stable. On the other hand equation 6 can be considered:

$$
\begin{gathered}
{\left[\mathrm{Ag}(\mathrm{CN})_{2}\right]^{-}{ }_{(\mathrm{aq})}+1 \mathrm{e}^{-} \Leftrightarrow \mathrm{Ag}^{0}{ }_{(\mathrm{s})}+2 \mathrm{CN}^{-}{ }_{(\mathrm{aq})}} \\
\mathrm{E}^{0}=-0.29 \mathrm{~V}
\end{gathered}
$$

And assuming that sodium dithionite oxidizes to sulphite:

$$
\begin{gathered}
2 \mathrm{SO}_{3}{ }^{2-}{ }_{(\mathrm{aq})}+2 \mathrm{H}_{2} \mathrm{O}+2 \mathrm{e}^{-} \Leftrightarrow \mathrm{S}_{2} \mathrm{O}_{4}{ }^{2-}{ }_{(\mathrm{aq})}+4 \mathrm{OH}^{-}{ }_{(\mathrm{aq})} \\
\mathrm{E}^{0}=-1.12 \mathrm{~V}
\end{gathered}
$$

The global reaction of precipitation is:

$$
\begin{gathered}
\mathrm{S}_{2} \mathrm{O}_{4}{ }^{2-}{ }_{\text {(aq) }}+4 \mathrm{OH}^{-}{ }_{(\mathrm{aq})}+2[\mathrm{Ag}(\mathrm{CN})]^{-}{ }_{(\mathrm{aq})} \Rightarrow 2 \mathrm{Ag}^{0}{ }_{(\mathrm{s})}+ \\
4 \mathrm{CN}^{-}{ }_{(\mathrm{aq})}+2 \mathrm{SO}_{3}{ }^{2-}{ }_{(\mathrm{aq})}+2 \mathrm{H}_{2} \mathrm{O}
\end{gathered}
$$

Under standard conditions, equation (8) presents $\Delta \mathrm{E}^{0}=$ $0.830 \mathrm{~V}$. Under the following experimental conditions: $25^{\circ} \mathrm{C}$; $\left[\mathrm{CN}^{-}\right]=0.0816 \mathrm{~mol} \mathrm{~L}^{-1} ;\left[\mathrm{SO}_{3}{ }^{2-}\right]=9.5 \times 10^{-3} \mathrm{~mol} \mathrm{~L}^{-1} ;\left[\mathrm{S}_{2} \mathrm{O}_{4}{ }^{2-}\right]$ $\left.=0.115 \mathrm{~mol} \mathrm{~L}^{-1} ;\left[\mathrm{OH}^{-}\right]=1 \times 10^{-2} \mathrm{~mol} \mathrm{~L}^{-1} ; \mathrm{AgCN}\right]=0.028$ mol L-1, the value of the potential is given by Nernst equation:

$$
\Delta E=\Delta E^{0}-\frac{R T}{n F} \ln \frac{\left[\mathrm{CN}^{-}\right]^{2}\left[\mathrm{SO}_{3}^{2-}\right]^{2}}{\left[\mathrm{~S}_{2} \mathrm{O}_{4}^{2-}\right]\left[\mathrm{OH}^{-}\right][\mathrm{AgCN}]^{2}}
$$

Applying logarithm base 10 and substituting into equation (9), was obtained the equation (10)

$$
\begin{gathered}
\Delta E=0.0830-\frac{0.059}{2} \\
\ln \frac{(0.0816)^{2}\left(9.5 \times 10^{-3}\right)^{2}}{(0.115)\left(1 \times 10^{-2}\right)^{4}(0.028)^{2}}=0.5992 \mathrm{~V}
\end{gathered}
$$

This confirms that the process under the conditions studied is favored from the thermodynamic view point.

\section{References}

1. Lamisse, M. G. Res. Discl. 1981, 201, 3-20.

2. Fleming, C. A. Hydrometallurgy 1992, 30, 127-162.

3. Lacoste, G.; Olive, H. U.K. Patent and Eur. Pat. Appl. 3732520. 1982.

4. Blair, A. Silver Plating, Metal Finish. 2002, 100, 284-290.

5. Sathaiyan, N.; Adaikkalam, P. J. Chem. Technol. Biot. 1992, 53, 121-130.

6. Rivera, I.; Patiño, F.; Cruells, M.; Roca, A.; Viñals, J. Rev. Metal. Madrid 2004, 40, 369-373.

7. King, J. US Patent US 3692291. 1984

8. Bogdan, L. C.; Galea, B.; Duschk, E.; Voilean, T. Rom. Patent RO 88164. 1995.

9. Deresypkina, G.; Sidnin, A.; Sheberstov, V. Poligrafiya 1983, 9, 23-32.

10. Foster, D. G.; Jorne, J. Meeting of the Electrochemical Society USA 1998, 573, 316-322.

11. Wilhelm, E.; Hofmann, H.; Kloeppel, J. DE Patent 3 034-102-22, 1982.

12. Atluri, V.; Raghavan, S. Precious and Rare Metal Technologies Book. Ed. Elsevier Science Publishers, Amsterdam Netherlands 1989, 291-295.

13. Nakamura, I. H. J. Imaging Sci. Techn. 1999, 39, 419-424.

14. Ballester, A.; Verdeja, L. F.; Sancho, J. Metalurgia Extractiva, Vol. 1 Fundamentos, Ed. Síntesis, Madrid, 2000, 182-189.

15. Lide, D. R. Handbook of Chemistry and Physics. Chemical Rubber Publishing Company, U.S.A. 72nd Edition, 1991-92, 6-3.

16. Jeffrey, M. I.; Brever, P. L.; Choo, W. L. Metall. Mater. Trans. B 2001, 32, 979-986. 
17. Rivera, I.; Roca, A.; Cruells, M.; Patiño, F.; Salinas, E. Hydrometallurgy 2007, 89, 89-98.

18. Rivera I. PhD Thesis: Estudio cinético de precipitación/lixiviación de Ag en el sistema $\mathrm{O}_{2}-\mathrm{S}_{2} \mathrm{O}_{3}{ }^{2-}-\mathrm{S}_{2} \mathrm{O}_{4}{ }^{2-}$. Aplicación a efluentes industriales, Universitat de Barcelona, Facultat de Química, España, 2003.

19. Barriga-Ordonez, F.; Nava-Alonso, F.; Uribe-Salas, A. Miner. Eng. 2006, 19, 117-122.
20. Parga, J. R.; Shukla, S. S.; Carrillo-Pedroza, F. R. Waste Manage. 2003. 23, 183-191.

21. Carrillo-Pedroza, F. R.; Nava-Alonso, F.; Uribe-Salas, A. Miner. Eng, 2000, 13, 541-548.

22. Gonzales-Lara, S. M.; Roca, A.; Cruells, M.; Patiño, F. Hidrometallurgy 2009, 1-2, 8-14.

23. Lourié, Y. Aide-mémoire de Chimie Analytique, $3^{\text {rd }}$ Ed, Éditions de Moscou, Moscou, 1975, 339. 